\title{
THE IMPLEMENTATION OF DIRECT METHOD TO IMPROVE STUDENTS’ ABILITY IN SPEAKING
}

\author{
Nurhayati Sitorus, Harpen Silitonga \\ Hayati.sitorus@gmail.com \\ UNIVERSITAS HKBP NOMMENSEN
}

\begin{abstract}
The purpose of this study is to investigate students' ability in speaking before and after using Direct Method in learning English. The method in this research was experimental quantitative method by using experimental design with one group pretest-posttest design. The design only saw students' achievement in speaking before and after using Direct Method. The object of the research was English Department students. They were randomly selected. The technique of collecting the data was done through oral test. The result of this study shown that the use of Direct Method could improve students' ability in speaking. It was proved from the students' average was higher after using Direct Method. The data in this research had normal distribution. Based on data analysis by using T-test was gotten that $\mathrm{t}_{\text {count }}=7,14$ at the significant level $\alpha=5 \%$ and $\mathrm{dk}(\mathrm{n}-1)=(40-1)$ $=39$ was gotten $t_{\text {table }}=1,82$. So, $t_{\text {count }}>t_{\text {table. }}$. It proved that $H_{o}$ was rejected and $H_{a}$ was accepted. It's meant that there was a significant difference between students' ability before and after implementing Direct Method.
\end{abstract}

Keywords: Direct Method, Speaking.

\section{A. INTRODUCTION}

English as an International language is placed as an important tool in economic, politic, business, facing MEA, and looking for a job. It is very necessary to be learnt. It has been taught at Elementry School, Junior High School, Senior High School, and university level. Now, English is not only necessary to be learnt but it is as a tool of self development for everyone especially for English Department students.

English Department students should have a skill. There are four skills in English, namely listening, speaking, reading, and writing. Speaking is an activity to deliver information or message to the other. According to Richard (2008: 19), "the mastery of speaking skill in English is a priority for many second language or foreign language learners". Therefore, it is a must for the students to acquire speaking skill.

However, speaking in English is a difficult thing that is faced by the students. It can be seen in the teaching learning process. When the lecturer asked the students, they were difficult to give the responses to speak in English. The same thing happened when they did presentation in front of the class. If the listeners asked the speakers they tended to write the answer first on their paper before answering the listeners' questions. It means that they can not do oral communication (speaking) directly in English. They just read the answer. Furthermore, students were difficult to pronounce the words based on the right punctuation. As the example, when the learners pronounced the word "about", some 
students pronounced it with the wrong pronunciation, namely "e'bawt". Regarding to the problems above, the effective method need to be applied in teaching speaking. Direct Method is regarded appropriate in teaching speaking.

\section{B. LITERATURE REVIEW}

Direct Method is a method designed where educator uses the target language (English) in the classroom. If some students do not know the meaning of the words that spoken by educator, the educator may not translate but s/he uses visual aids or through demonstrations to illustrate the meaning of the words (Titone in Richards and Rodgers, 2001:12). The use of visual aids in Direct Method will make students be fun to learn English. In Direct Method, vocabulary is taught every meeting. So, it can enrich their vocabulary. If they have enough vocabulary they will able to speak. Then, grammar is taught inductively. Through this method, students will be motivated to improve their ability in speaking. Therefore, a research entitled "Implementation of Direct Methods to Improve Students' Ability in Speaking".

Richards and Rodgers in Brown (2001) stated the principles of Direct Method as follow:

1. Classroom was conducted exclusively in the target language;

2. Only everyday vocabulary and sentences were taught;

3. Oral communication skills has build in a carefully graded progression organized around question and answer exchanges between teachers and students in small, intensive class;

4. Grammar was taught inductively;

5. New teaching points were introduced orally;

6. Concrete vocabulary was taught through demonstration, objects, and pictures, whereas abstract vocabulary was taught by association of ideas;

7. Both speech and listening comprehension were taught;

8. Correct pronunciation and grammar were emphasizes.

In addition, there are several stages in implementing Direct Method as proposed by Norland and Terry (2006) as follow:

1. The teacher shows a set of pictures that often portray life in the country of the target language.

2. The teacher describes the picture in the target language.

3. The teacher asks questions in the target language about the picture.

4. Students answer the questions as best they can using the target language. Pronunciation is corrected, but grammatical structure is not.

5. Students may also read a passage in the target language.

6. The teacher asks questions in the target language about the reading.

7. Students answer questions as best they can using the target language.

\section{RESEARCH METHODOLOGY}

The research method used in this research was experimental quantitative method. The population of the research was English Department students. They consisted of three classes (A, B, and C). Each class consisted of 40 students. And the writer took the sample randomly. The sample was group A that consisted of 40 students. The instrument used in this research was oral test. The students were asked to do oral communication (speaking) in front of the class. There were some aspects that the writer used to asses the students's 
Sitorus \& Silitonga: The Implementation of Direct....

ability in speaking. They were grammar, vocabulary, comprehension, fluency, pronunciation, and task. The data obtained were analyzed by using T-test.

\section{FINDINGS AND DISCUSSION}

After the writer knew the results of the students' ability before and after using Direct Method, then the writer made the table of frequency distribution. It was done to know the mean, standart deviation, and standart error from the data (Pre-test and post-test).

Table 1

The Distribution of Students' Score Frequency in Speaking (Pre test)

\begin{tabular}{cccccc}
\hline $\mathrm{X}$ & $\mathrm{F}$ & $\mathrm{Fx}$ & $\mathrm{x}$ & $\mathrm{x}^{2}$ & $\mathrm{fx}^{2}$ \\
\hline 45 & 5 & 225 & $-13,75$ & 189,06 & 945,3 \\
50 & 6 & 300 & $-8,75$ & 76,56 & 459,36 \\
55 & 5 & 275 & $-3,75$ & 14,06 & 70,3 \\
60 & 10 & 600 & 1,25 & 1,56 & 15,6 \\
65 & 8 & 520 & 6,25 & 39,06 & 312,48 \\
70 & 4 & 280 & 11,25 & 126,56 & 506,24 \\
75 & 2 & 150 & 16,25 & 264,06 & 528,12 \\
& $\mathrm{~N}=40$ & $\sum \mathrm{fX}=2350$ & & & $\sum \mathrm{fx}^{2}=2837,4$ \\
\hline
\end{tabular}

From the data above shown that the highest score is 75 in pre test. And the mean score of the data above was 58,75 , the standart deviation was 8,42 , and standart error of the group was 1,35 .

Table 2

The Distribution of Students' Score Frequency in Speaking (Post test)

\begin{tabular}{cccccc}
\hline $\mathbf{X}$ & $\mathbf{F}$ & $\mathbf{F x}$ & $\mathbf{X}$ & $\mathbf{X}^{\mathbf{2}}$ & $\mathbf{f x}^{\mathbf{2}}$ \\
60 & 4 & 240 & -15 & 225 & 900 \\
65 & 3 & 195 & -10 & 100 & 300 \\
70 & 8 & 560 & -5 & 25 & 200 \\
75 & 9 & 675 & 0 & 0 & 0 \\
80 & 8 & 640 & 5 & 25 & 200 \\
85 & 6 & 510 & 10 & 100 & 600 \\
90 & 2 & 180 & 15 & 225 & 450 \\
& $\mathbf{N = 4 0}$ & $\sum \mathbf{f X = 3 0 0 0}$ & & & $\sum \mathbf{f x}^{2}=\mathbf{2 6 5 0}$ \\
\hline
\end{tabular}

From the data above shown that the highest score in post test was 90 . And the mean score of the data above was 75 , the standart deviation was 8,14 , and standart error of the group was 1,30.After the writer knew the mean, standart deviation and the error before and after using Direct Method, then the writer analyzed the data. Data analysis was done by using Liliefors normality test, testing homogeneity F, and testing hypothesis by using T-test.

\section{Normality Test for Pre-Test Group (X)}

The normality test that the writer used was normality test by Lilliefors. The table of normality test for variable $\mathrm{X}$ could be seen below. 
Table 3

The Normality test for Pre-Test Group

\begin{tabular}{llllllll}
\hline $\mathbf{X}$ & $\mathbf{F}$ & $\mathbf{f K u m}$ & $\mathbf{Z i}$ & $\mathbf{T a b l e}$ & $\mathbf{F}(\mathbf{Z i})$ & $\mathbf{S}(\mathbf{Z i})$ & $\mathbf{L}$ \\
45 & 5 & 5 & $-1,63$ & $-0,4484$ & 0,0516 & 0,125 & 0,0734 \\
50 & 6 & 11 & $-1,04$ & $-0,3508$ & 0,1492 & 0,275 & $\mathbf{0 , 1 2 5 8}$ \\
55 & 5 & 16 & $-0,44$ & $-0,1700$ & 0,3300 & 0,4 & 0,07 \\
60 & 10 & 26 & 0,15 & 0.0596 & 0,5596 & 0,65 & 0,0904 \\
65 & 8 & 34 & 0,74 & 0,2704 & 0,7704 & 0,85 & 0,0796 \\
70 & 4 & 38 & 1,34 & 0,4099 & 0,9099 & 0,95 & 0,0401 \\
75 & 2 & 40 & 1,93 & 0,4732 & 0,9732 & 1 & 0,0268 \\
\hline \multicolumn{7}{c}{$\mathbf{M}_{\mathbf{x}}=58,75 ; \mathrm{N}=40 ; \mathrm{S}=8,42$} &
\end{tabular}

Based on the table above, the greatest value among the absolute value $\left(\mathrm{L}_{\text {count }}\right)=0,1258$. Then, $\mathrm{L}_{\text {count }}$ was consulted with critical value (L) at the level $\alpha=0,05(5 \%)$. Where $\mathrm{N}=40$, So, $\mathrm{L}_{\text {count }}<\mathrm{L}_{\text {table }}(0,1258<0,140)$. It proved that the data of variable $\mathrm{X}$ were normally distributed.

\section{The Normality Test for Post-Test Group}

The normality test that the writer used was normality test by Lilliefors. The table of normality test for variable Y could be seen below.

Table 4

The Normality Test for Post-Test Group

\begin{tabular}{llllllll}
\hline $\mathbf{X}$ & $\mathbf{F}$ & $\mathbf{f K u m}$ & $\mathbf{Z i}$ & $\mathbf{T a b e l}$ & $\mathbf{F}(\mathbf{Z i})$ & $\mathbf{S}(\mathbf{Z i})$ & $\mathbf{L}$ \\
60 & 4 & 4 & $-1,84$ & $-0,4671$ & 0,0329 & 0,1 & 0,0671 \\
65 & 3 & 7 & $-1,23$ & 0,3907 & 0,1093 & 0,175 & 0,0657 \\
70 & 8 & 15 & $-0,61$ & 0,2291 & 0,2709 & 0,375 & $\mathbf{0 , 1 0 4 1}$ \\
75 & 9 & 24 & 0 & 0 & 0,5000 & 0,6 & 0,1 \\
80 & 8 & 32 & 0,61 & 0,2291 & 0,7291 & 0,8 & 0,0709 \\
85 & 6 & 38 & 1,23 & 0,3907 & 0,8907 & 0,95 & 0,0593 \\
90 & 2 & 40 & 1,84 & 0,4671 & 0,9671 & 1 & 0,0329 \\
\hline
\end{tabular}

$M_{x}=75 ; N=40 ; S=8,14$

Based on the table above, the greatest value among the absolute value $\left(\mathrm{L}_{\text {count }}\right)=0,1040$. Then, $\mathrm{L}_{\text {count }}$ was consulted with critical value (L) at the level $\alpha=0,05(5 \%)$. Where $\mathrm{N}=40$, So, $\mathrm{L}_{\text {count }}<\mathrm{L}_{\text {table }}(0,1040<0,140)$. It proved that the data of variable $\mathrm{Y}$ were normally distributed.

\section{Testing Homogeneity}

The homogeneity test of variance is used to test the equality of variables. The method used is Barlet's test (Sudjana, 1989:261). The calculation can be seen below.

$\mathrm{Sx}^{2}=(8,42)^{2}=70,89$

$\mathrm{Sy}^{2}=(8,14)^{2}=66,26$ 
Sitorus \& Silitonga: The Implementation of Direct....

After the writer obtained the values that use for Bartlet's test, then the writer calculated combined variance of all samples $\left(S_{2}\right)$, the value for $\mathrm{B}$, and the writer used the statistics chi square $\left(\chi^{2}\right)$. The calculation of the homogeneity data as the following.

Table 5

The Necessary Values for Bartlett's Test

\begin{tabular}{llllll}
\hline Sample & $\mathbf{D f}$ & $\mathbf{1 / d f}$ & $\mathbf{S i}_{\mathbf{i}}{ }^{\mathbf{2}}$ & $\mathbf{L o g} \mathbf{S}_{\mathbf{i}}^{\mathbf{2}}$ & $(\mathbf{d f}) \mathbf{L o g} \mathbf{S}_{\mathbf{i}}{ }^{\mathbf{2}}$ \\
$\mathrm{X}$ & 39 & 0,025 & 70,89 & 1,85 & 72,17 \\
$\mathrm{Y}$ & 39 & 0,025 & 66,26 & 1,82 & 71,03 \\
& $\mathbf{7 8}$ & & & & $\mathbf{1 4 3 , 2 0}$ \\
\hline
\end{tabular}

\section{a.The Combined Variance of the Sample}

$$
\begin{aligned}
S^{2} & =\frac{\sum\left(n_{i}-i\right) S_{i}{ }^{2}}{\sum\left(n_{i}-1\right)} \\
& =\frac{\left(n_{x}-1\right) S_{x}{ }^{2}+\left(n_{Y}-1\right) S_{y}{ }^{2}}{\left(n_{x}+n_{y}\right)-2} \\
& =\frac{(39)(70,89)+(39)(66,26)}{64} \\
& =\frac{(2764,71)+(2584,14)}{78} \\
& S^{2}=68,575 \\
& \log S^{2}=\log 68,575=1,84
\end{aligned}
$$

\section{b. The Value for $B$}

$$
\begin{aligned}
B & =\log S^{2} \sum\left(n_{i}-1\right) \\
& =(1,84)(78) \\
& =143,52
\end{aligned}
$$

\section{c. Bartlett's Test by Using Chi Square}

$$
\begin{aligned}
X^{2} & =\ln 10 \quad\left\{B-\sum\left(n_{i-1}\right) \log S^{2}\right\} \\
& =(2,3026)(143,52-143,20) \\
& =(2,3026)(0,32) \\
& =0,736
\end{aligned}
$$

From the calculation above was gotten $X^{2}$ count (chi square) $0,736, X^{2}$ table at the level of trust $95 \%$ with df 39 was 54,572 . That's why, $X_{\text {count }}^{2}<X_{\text {table, }}^{2}(0,736<54,572)$. It proved that the variance of population was homogen.

\section{Testing Hyphothesis}

To test the hyphothesis, the writer used T-test (Sudijono, 2007: 282-285):

$$
t_{o}=\frac{M_{1}-M_{2}}{S E_{M_{1}-M_{2}}}
$$




$$
\begin{gathered}
=\frac{75-58,75}{1,87} \\
=8,689 \\
\text { So, } \mathrm{t}_{\text {count }}=8,69
\end{gathered}
$$

Based on the data above, $\mathrm{t}_{\text {count }}=8,69$ at the significant level $\alpha=5 \%, \mathrm{dk}(\mathrm{n}-1)=(40-1)=$ 39 so, $t_{\text {table }}=1,68$. It could be concluded that $t_{\text {count }}>t_{\text {table }}(8,69>1,68)$. It meant that $H_{o}$ was rejected dan $\mathrm{H}_{\mathrm{a}}$ was accepted. It stated that there was a significant differences between students' ability before and after implementing the Direct Method in speaking.

Based on the normality and homogeneity test, the data before and after doing treatment has normal distribution and has same variance. And based on data analysis by using $\mathrm{T}$ test was gotten that $\mathrm{t}_{\text {count }}=7,14$ at the significant level $\alpha=5 \%$ and $\mathrm{dk}(\mathrm{n}-1)=(40-1)=39$ was gotten $t_{\text {table }}=1,82$. So, $t_{\text {count }}>t_{\text {table. }}$. t proved that $\mathrm{H}_{\mathrm{o}}$ was rejected and $\mathrm{H}_{\mathrm{a}}$ was accepted. It means that there was a significant difference between students' ability before and after implementing Direct Method.

Based on the result that has been described above that Direct Method is a teaching method can improve students' ability in speaking by using English as introduction language. Here, the educator uses English when s/he explain the lesson. And in the classroom, the students are not permitted to use Indonesian language when they ask something to the educator or communicate to the educator or their friends. In this case, the educator must be able to describe the words that the students do not know by using visual aid or explain them by using her words. There is no translation here. That's why the students try and try to speak in English and at last, they are able to speak in English.

\section{E. CONCLUSION AND SUGGESTION}

From the dara above, it can be concluded that students' ability increased after using Direct Method. It can be seen from the mean of students' achievement before and after using Direct Method, namely 58,75 be 75 and the percentage of students' achievement also increase $(57,5 \%$ be $62,5 \%)$. It is proved that the using of Direct Method can improve the students' ability in speaking. Therefore, English teachers should improve the teaching of English poetry by providing activities that can increase students' interest in reading poetry such as poetry reading contest, making the poetry surgical group and so on.

\section{F. REFERENCES}

Brown, H. Douglas. (2001). Teaching by Principles: An Interactive Approach to Language Pedagogy. Second Edition. White Plains. NY: Pearson Education.

Norland, L. Deborah and Terry Pruett. (2006). A Kaleidoscope of Models and Strategies for Teaching English to Speakers of Other Language. Sard Wesport: CT. Libbraries Unlimited/ Teacher Ideas Press.

Richards, JC and TS Rodgers. (2001). Language Teaching-"Approaches and Methods in Language Teaching". Cambridge: Cambridge University Press.

Richard, J.C. (2008). Teaching Listening and Speaking from Theory to Practice. New York: Cambridge University Press, 2008. 